\title{
CLARK'S NUTCRACKER AT MOOSE JAW
}

by D. S. Green, 346 Acadia Drive, Saskatoon

On March 24, 1968, while driving through River Park, south of Moose Jaw, with M. E. Hacking, I saw a Clark's Nutcracker (Nucifraga columbiana) just south of Blackfoot Bridge, near the former Walter Riome property. I am familiar with this bird from Banff and Jasper National Parks and Mr. Hacking has had several years with the Alberta and British Columbia Forestry Services and also knows the "camp robber" well. The nutcracker was scavenging for food in an area much used for picnics.

I reported the sighting at the time to F. G. Bard, Director of the Saskatchewan Museum of Natural History, who told me that only four previous sightings had been reported for the province.
[Editor's Note: The last observation of a Clark's Nutcracker in Saskatchewan previous to Mr. Green's record at Moose Jaw was a sighting by Fred Bard on October 8, 1963, reported to the Blue Jay $(22: 4)$. At that time three other records were known (a specimen collected at Ravenscrag, September 19, 1919 by Spencer Pearse, who noted several on his ranch that year; one seen in September, 1925 by Pearse; and one reported at Ravenscrag on August 18, 1960 by Robert Folker). These three records, and Mr. Bard's 1963 abservation, were all from the $\mathrm{Cy}$ press Hills area of Saskatchewan, so the new record from Moose Jaw represents an extension of the straggler's range.]

\section{BILL DEFORMITY IN CLARK'S NUTCRACKER}

by D. S. Green, 346 Acadia Drive, Saskatoon

During our summer vacation in early July, 1968 we made an interesting observation at "Camp" Edith Cavell in Jasper National Park concerning Clark's Nutcracker. A great many birds of this species are to be seen in this area and one which we observed had a most unusual deformity - the bill being severeiy twisted and about half again as long as usual (see sketch). Nevertheless the bird seemed well-fed and active, although in part this might be attributed to the

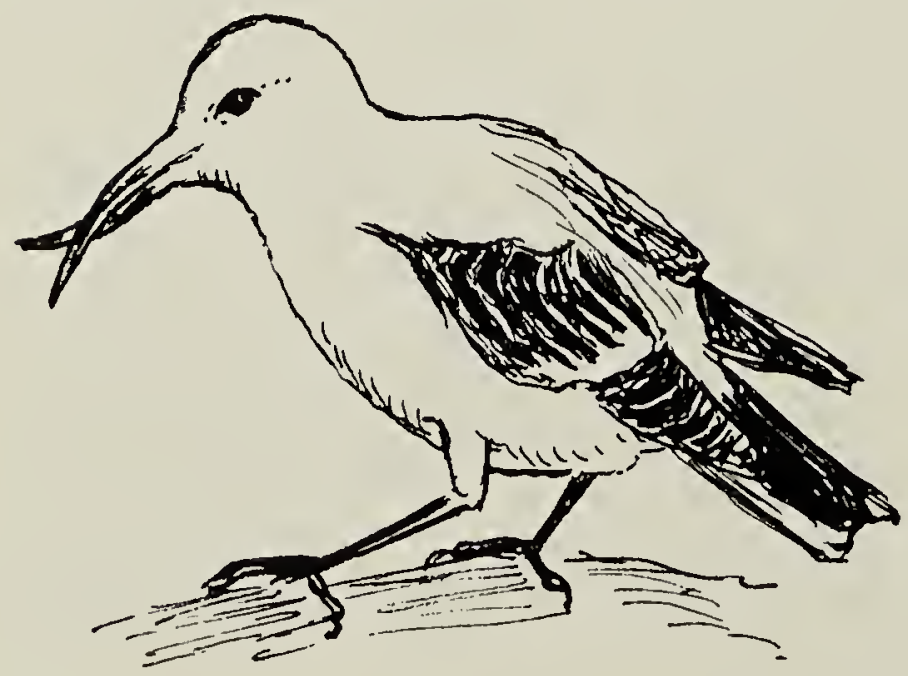

"easy living" provided by tourists in the form of nuts, crumbs, etc.

Several possible causes of this deformity have been suggested to me. Deformed bills are often thought to result from genetic change or an error in development. Injury at an early age or dietary deficiency or imbalance might be responsible for the abnormal development.

\section{CO-OPERATIVE SPRING MIGRATION STUDY}

Records are again requested for the continent-wide survey being made under the auspices of the U.S. Fish and Wildlife Service. For a list of species studied, see Blue Jay, September 1968, Vol. 26, \#3, pp. 132-3. All records should be submitted by June 15, 1969 to:

Mrs. Mary Houston, 863 University Drive, Saskatoon, Sask. 